\title{
Factors Related to the Incidence of ICU-acquired Infections in Iran: Analysis of National Data
}

\author{
Iran'da Yoğun Bakım Ünitesinden Edinilen Enfeksiyonların Insidansına Illişkin Faktörler: \\ Ulusal Verilerin Analizi
}

\author{
(1) Neda IZADI ${ }^{1}$, (1) Yadollah MEHRABI ${ }^{1}$, (1) Koorosh ETEMAD ${ }^{1}$, (1) Babak ESHRATI ${ }^{2}$, (1) Seyed-Saeed HASHEMI-NAZARI ${ }^{3}$ \\ 1Shahid Beheshti University of Medical Sciences, School of Public Health and Safety, Department of Epidemiology, Tehran, Iran \\ 2Iran University of Medical Sciences, School of Medicine, Department of Social Medicine, Tehran, Iran \\ 3 Prevention of Cardiovascular Disease Research Center, Department of Epidemiology, School of Public Health and Safety, Shahid Beheshti \\ University of Medical Sciences, Tehran, Iran
}

\section{Abstract}

Introduction: Patients admitted to intensive care units (ICUs) are particularly susceptible to hospital-acquired infections (HAls). This study aimed to investigate factors related to the incidence of ICU-Als in Iran.

Materials and Methods: In this study, Iranian nosocomial infections surveillance and hospital statistics and information system were used to collect data on patients with HAls in 2018. The data was expanded based on 12 months of the year (13,632 records in terms of "hospital-ward-month") and then, the last observation carried forward method was used to replace the missing data. The generalized negative binomial regression with "patientdays" as an offset variable was used to identify the factors affecting the incidence of ICU-Als.

Results: Of the patients $22.92 \%, 5.76 \%, 13.62 \%, 43.41 \%$, and $14.29 \%$ of were in neonatal ICU, pediatric ICU (PICU), internal ICU, general ICU, and surgical ICU (SICU), respectively. The most common ICU-Als were ventilator-associated events (VAE) and urinary catheter-related infections (UTI). Based on multivariable regression, the number of death [incidence rate ratio $(I R R)=1.02$ ], the number of device-related infections (IRR=1.1), ward type [PICU (IRR=1.58), internal ICU (IRR=1.63), general ICU $(I R R=1.53)$ and SICU $(I R R=1.47)]$, bed occupancy rate indicator $(I R R=1.17$ for moderate conditions), hospital's accreditation (IRR=1.23 and IRR=1.73 for accreditation 1 and 2, respectively) and hospital's expertise were associated with an increase in ICU-Als incidence.

Conclusion: Based on the results, the most common ICU-Als were VAE and UTI. Therefore, to reduce incidence of ICU-Als, full hygiene control should be performed by the medical staff. Ventilators and catheters should be used in special circumstances with minimum duration.

Keywords: Risk, hospital acquired infections, intensive care units, Iran

\section{Öz}

Giriş: Yoğun bakım ünitelerine (YBÜ) kabul edilen hastalar, özellikle hastane kaynaklı enfeksiyonlara (HKE) duyarlıdırlar. Bu çalışma, İran'da YBÜ kaynaklı enfeksiyonların (YBÜ-KE) insidansı ile ilgili faktörleri araştırmayı amaçlamıştır.

Gereç ve Yöntem: Bu çalışmada, 2018 yılında, HKE'li hastaların verilerini toplamak için İran hastane enfeksiyonları sürveyansı ve hastane istatistik ve bilgi sistemi kullanıldı. Veriler yılın 12 ayı baz alınarak genişletildi ("hastane-servis-ay" açısından 13.632 kayıt) ve daha sonra, eksik verilerin yerini alması için son gözlemin kaydedilmesi yöntemi kullanılmıştır. YBÜ-KE insidansını etkileyen faktörleri belirlemek için bir denge değişkeni olarak "hasta-günleri" ile genelleştirilmiş negatif binom regresyon kullanıldı.

Cite this article as: Izadi N, Mehrabi Y, Etemad K, Eshrati B, Hashemi-Nazari SS. Factors Related to the Incidence of ICU-acquired Infections in Iran: Analysis of National Data. Mediterr J Infect Microb Antimicrob. 2022;11:6.

Address for Correspondence/Yazışma Adresi: Seyed-Saeed Hashemi-Nazari MD, Prevention of Cardiovascular

Disease Research Center, Department of Epidemiology, School of Public Health and Safety, Shahid Beheshti

University of Medical Sciences, Tehran, Iran

E-mail: saeedh_1999@yahoo.com, nedaizadi2255@gmail.com

ORCID ID: orcid.org/0000-0002-0883-3408

Received/Geliş Tarihi: 01.09.2021 Accepted/Kabul Tarihi: 18.11.2021

- Copyright 2022 by the Infectious Diseases and Clinical Microbiology Specialty Society of Turkey

Mediterranean Journal of Infection, Microbes and Antimicrobials published by Galenos Yayinevi. 
Bulgular: Hastaların sırasıyla \%22,92, \%5,76, \%13,62, \%43,41 ve \%14,29'u yenidoğan YBÜ'de, çocuk YBÜ'de (ÇYBÜ), dahili YBÜ, genel YBÜ ve cerrahi YBÜ'de idi. En yaygın YBÜ-KE'ler ventilatör ilişkili olaylar ve kateter ilişkili üriner sistem enfeksiyonları idi. Çok değişkenli regresyon analizine göre; YBÜ-KE insidansında artış, ölüm sayısı (IRR=1,02), cihazla ilgili enfeksiyon sayısı (IRR=1,1), servis tipi [ÇYBÜ (IRR=1,58), dahili YBÜ (IRR=1,63), genel YBÜ $(I R R)=1,53]$ ve cerrahi YBÜ $(I R R=1,47)]$, yatak doluluk oranı göstergesi (orta koşullar için IRR=1,17), hastanenin akreditasyonu (sırasıyla akreditasyon 1 ve 2 için IRR=1,23 ve IRR=1,73) ve hastanenin uzmanlığı ile ilişkiliydi.

Sonuç: Sonuçlara göre, en yaygın YBÜ-KE'ler ventilatörle ilişkili olaylar ve üriner kateterle ilişkili enfeksiyonlar idi. Bu nedenle, YBÜ-KE insidansını azaltmak için tıbbi personel tarafından tam hijyen kontrolü yapılmalıdır. Ventilatör ve kateterler özel durumlarda ve minimum süre ile kullanılmalıdır. Anahtar Kelimeler: Risk, hastane enfeksiyonları, yoğun bakım üniteleri, İran

\section{Introduction}

Hospital-acquired infections (HAls) are a major health concern worldwide and are regarded as the most common complications in any healthcare facility ${ }^{[1]}$. According to the European Center for Disease Prevention and Control estimates, more than 2.5 million cases of HAls occur annually in Europe ${ }^{[2]}$. Additionally, in the United States, HAls account for 100,000 deaths annually ${ }^{[2]}$.

Patients who are admitted to intensive care units (ICUs) are particularly susceptible to HAls, with higher morbidity of HAls than other hospital wards, which are often severe ${ }^{[2,3]}$. Intensive care unit-Als affect patient's safety in developing and developed countries and are considered responsible for a substantial proportion of disability, increased length of stay (LOS) and mortality, recovery process delays, and impose additional costs and financial burden on the healthcare system of countries ${ }^{[4,5]}$.

Studies on infection in the ICU in Europe demonstrated a significantly higher $(20.6 \%)$ prevalence of ICU-Als ${ }^{[6]}$. The important ICU-Als include ventilator-associated pneumonia/ ventilator-associated events (VAE), urinary catheter-related infections (UTI), central line-associated bloodstream infections (CLABSI), and surgical site infections (SSI) ${ }^{[6,7]}$. Additionally, a meta-analysis study by Ling et al ${ }^{[8]}$ in Southeast Asia revealed that the pooled incidence of HAI was 20 patients per 1,000 ICUdays.

The majority of these infections are associated with aging, disease severity, and healthcare factors including the increased use of invasive devices (endotracheal tubes, tracheostomy, central venous and urinary catheterization, and mechanical ventilation), type of provided health services, and inappropriate use of antimicrobial drugs ${ }^{[6,7,9]}$.

Hence, HAls prevention is now the most successful intervention, and the recognition of the magnitude of related factors to the incidence of ICU-Als has become essential for adopting proper infection control measures and reducing the incidence of infection in hospitals especially in the ICU. Therefore, this study aimed to investigate the related factors in the incidence of ICU-AI in Iran.

\section{Materials and Methods}

\section{Data Sources}

This study used the Iranian nosocomial infection surveillance (INIS) and hospital statistics and information system (AVAB) to collect data on patients with HAls from 662 hospitals in 2018. The national infection control committee registers data to reduce mortality, morbidity, and complications of HAls. This study used the HAls including the following: bone and joint, central nervous system, eye, ear, nose, throat, or mouth, and UTI, VAE, SSIs, CLABSI, gastrointestinal system infections, reproductive tract infections, and skin and soft tissue infections.

The INIS collects data from approximately 863 hospitals and records different types of information in different units of each hospital including age, gender, type of HAls, number of hospitalizations, patient-day, number of deaths, number of surgeries, date of infection, province, university, affiliated organization, devices used, and infection outcome. Additionally, performance indicators were extracted including the average LOS, occupancy rate, and bed turnover from AVAB, which is a web-based system for each hospital.

\section{Expanded Data and Missing Data Imputation}

The data including 12,586 records in terms of "hospital-wardmonth" for ICU-Als was expanded based on the 12 months of the year (13,632 records in terms of "hospital-ward-month") and then, the last observation carried forward (LOCF) method was used to replace the missing data. In the LOCF imputation, first, the data on each variable in each hospital ward was sorted in terms of months, and the last observation was replaced through the forward method; then, the data on the same variable was sorted in reversed order of the months and the last observation was replaced for the missing values through the backward method. Finally, the obtained average values in the two steps of the forward and backward methods were used as the missing data value. Additionally, the hospitals without data on the number of infections and hospitalizations (in none of the months under the study) were excluded. Final ICU-Als include 10,836 records obtained from 579 hospitals. 


\section{The National Standard for Hospital Performance Indicators}

The hospital performance indicators were categorized based on the standards of the Ministry of Health and Medical Education of Iran as follows:

Average LOS (day): $<3.5$ (desirable), 3.5-4 (moderate), and $>4$ (undesirable),

Bed occupancy rate (\%): >70 (desirable), 60-70 (moderate), and $<60$ (undesirable),

Bed turnover rate: $>24$ (desirable), 17-24 (moderate), and $<17$ (undesirable),

Death-to-bedridden ratio (\%): <2 (desirable), 2-3 (moderate), and $>3$ (undesirable).

Additionally, the national average rate of bed turnover (134.24) and bed occupancy (62.73) were used to plot the Pabon Lasso graphical chart. The plotted Pabon Lasso graph indicates four zones, where zone I is the inefficient area, zone II, zone III is the efficient area of the model, and zone IV.

\section{Statistical Analysis}

Mean (standard deviation), median [interquartile range (IQR)], and count (percentage) were used to describe quantitative and qualitative variables, respectively.

Generalized negative binomial regression was used with "patient-days" as an offset variable to identify the factors that affect the ICU-Als incidence. All variables with a $p$ value of $<0.2$ at the univariable model were entered into the multivariable regression model. Data were analyzed using the Stata (version 12) and $p<0.05$ was considered statistically significant for all statistical tests.

\section{Results}

The median age of patients was $57.5(I \mathrm{QR}=55.09)$ years. The median hospitalization length until infection and hospital LOS in the patients was $8.28(\mathrm{IQR}=12.8)$ days and $21 \quad(\mathrm{IQR}=21.75)$ days, respectively. The highest median of the number of death was observed in the internal ICU $(7, I Q R=10)$. The distributions of different variables by the type of ICU in Iran hospitals are shown in Table 1.

Totally, $22.92 \%, \quad 5.76 \%, \quad 13.62 \%, 43.41 \%$, and $14.29 \%$ of patients were in neonatal ICU (NICU), pediatric ICU (PICU), internal ICU, general ICU, and surgical ICU (SICU), respectively. The rate of ICU-Als was 24.6, 21.3, 20.9, 10.1, and 7.6 per 1,000 patient-days for internal ICU, general ICU, SICU, PICU, and NICU, respectively. The most common ICU-Als were VAE (6.49 per 1,000 patient-days) and UTI (3.32 per 1,000 patient-days). Based on the hospital expertise and type, 90.53\% and 63.87\% of hospitals were general hospitals and medium hospitals (bed size $=100-320$ ), respectively. Additionally, based on the Pabon Lasso model, only $13.73 \%$ of hospitals were in the efficient zone (zone III) (Table 2). Considering the performance indicators, including average LOS, bed occupancy, and bed turnover, the frequency of desirable conditions was higher in hospitals (Figure 1).

\section{The Risk of ICU-Als}

The investigation in the relationship between ICU-AI incidence and hospital variables and indicators revealed the association in the number of death (death in HAls patients) and increased ICUAl incidence [incidence rate ratio (IRR) $=1.02 ; 95 \%$ confidence interval (Cl): 1.01-1.02]. Based on multivariable generalized negative binomial regression, the number of device-related infections (catheters and ventilators) was associated with a 10\% increased ICU-AI incidence rate (IRR=1.1; 95\% Cl: 1.08-1.13). Additionally, PICU, internal ICU, general ICU, and SICU were associated with a $58 \%, 63 \%, 53 \%$, and $47 \%$ increase ICU-AI incidence rate compared to the NICU, respectively. Considering the hospital's expertise, the largest increase in ICU-Al incidence was related to the heart hospitals (IRR $=2.91 ; 95 \% \mathrm{Cl}: 2.37-3.57)$, accidents (IRR=2.08; 95\% $\mathrm{Cl}: 1.6-2.71)$, and pediatric hospitals (IRR=1.95; 95\% Cl: 1.67-2.27). Additionally, the risk of an increased ICU-AI incidence was 23\% (IRR=1.23; 95\% Cl: 1.121.35) and $73 \%$ (IRR=1.73; 95\% Cl: 1.52-1.97) higher in hospitals with accreditation 1 and 2, respectively. Hospitals with moderate conditions in terms of bed occupancy rate indicator have a 1.17 times higher ICU-AI incidence rate than the desirable conditions (IRR=1.17; 95\% Cl: 1.09-1.25) (Table 3).

The univariable regression revealed that ventilator-related infections, catheter-related infections, and the number of surgery in hospitals were associated with an increased ICU-AI incidence, but these variables were not statistically significant in multivariable regression. As the hospital bed surgery turnover increases, the incidence rate of infections decreases by $1 \%$ (IRR=0.99; 95\% Cl: 0.99-0.99) (Table 3).

\section{Discussion}

The incidence of HAls depends on many factors, including medical interventions, hospital factors, and personal characteristics. Additionally, it varies in different hospital wards. The longer ICU LOS and the use of invasive devices increase the rate of HAls in these wards although the ICU has increased recovery rate and reduced mortality ${ }^{[0]}$.

Results revealed that the number of death (death in patients with HAls), type of ICU, hospital's expertise, and bed occupancy rate indicator were associated with an increased ICU-Al incidence rate. Knowing the causes, type, and frequency of HAls can be very effective in the optimal management and improvement of quality services. Therefore, organizing the nosocomial infection 
Table 1. The distribution of different variables by the type of ICU in Iran hospitals in 2018

\begin{tabular}{|c|c|c|c|c|c|c|c|}
\hline Variable & $\begin{array}{l}\text { Hospitalization } \\
\text { length until } \\
\text { infection (day) }\end{array}$ & $\begin{array}{l}\text { Hospital LOS } \\
\text { (day) }\end{array}$ & Mean age & $\begin{array}{l}\text { Bed occupancy } \\
\text { rate }\end{array}$ & $\begin{array}{l}\text { Bed turnover } \\
\text { rate }\end{array}$ & $\begin{array}{l}\text { Number of } \\
\text { death }\end{array}$ & $\begin{array}{l}\text { Number of } \\
\text { surgery }\end{array}$ \\
\hline \multicolumn{8}{|l|}{ NICU } \\
\hline $\mathrm{N}$ & 2484 & 2172 & 2484 & 2388 & 2388 & 2484 & 2484 \\
\hline Mean (SD) & $10.55(22.8)$ & $21.83(24)$ & 15.44 (33.69) & 69.59 (12.07) & 171.05 (911.05) & $\begin{array}{l}12.03 \\
(452.16)\end{array}$ & $1.98(15.58)$ \\
\hline Median (IOR) & $6(10)$ & $17(19.66)$ & $0(1)$ & 70.9 (16.52) & $98.63(41.33)$ & $1(4)$ & $0(0)$ \\
\hline \multicolumn{8}{|l|}{ PICU } \\
\hline $\mathrm{N}$ & 624 & 576 & 624 & 600 & 600 & 624 & 624 \\
\hline Mean (SD) & $14.22(17.1)$ & $27.94(24.76)$ & 19.27 (28.97) & 74.8 (10.68) & $90.25(25.63)$ & $4.18(4.18)$ & $5.72(14.82)$ \\
\hline Median (IQR) & $10(14)$ & $21.16(21.5)$ & $5(14.61)$ & 76.41 (13.07) & 83.99 (27.38) & $3(5)$ & $0(4)$ \\
\hline \multicolumn{8}{|l|}{ Internal ICU } \\
\hline $\mathrm{N}$ & 1476 & 1344 & 1476 & 1452 & 1452 & 1476 & 1476 \\
\hline Mean (SD) & $13.33(13.23)$ & $29.96(27.97)$ & $61.68(18.04)$ & 70.98 (13.95) & 88.52 (32.39) & $9.36(8.89)$ & $8.22(28.3)$ \\
\hline Median (IQR) & $10.33(13.5)$ & $25(22.2)$ & $65.6(18.25)$ & $73.1(17.44)$ & $82.45(29.8)$ & $7(10)$ & $0(6)$ \\
\hline \multicolumn{8}{|l|}{ General ICU } \\
\hline $\mathrm{N}$ & 4704 & 4368 & 4704 & 4584 & 4584 & 4704 & 4704 \\
\hline Mean (SD) & $14.13(25.17)$ & $26.67(29.52)$ & 60.7 (18.99) & $65.15(16.12)$ & 147.71 (736.67) & $7.97(7.74)$ & $12.41(33.29)$ \\
\hline Median (IOR) & 8.25 (13.03) & $20.57(21.5)$ & $65.21(23.98)$ & $66.83(21.23)$ & $92.56(40.07)$ & $6(8)$ & $1(11)$ \\
\hline \multicolumn{8}{|l|}{ Surgical ICU } \\
\hline $\mathrm{N}$ & 1548 & 1416 & 1548 & 1524 & 1524 & 1548 & 1548 \\
\hline Mean (SD) & $13.78(15.33)$ & $29.26(23.06)$ & $55.78(17.5)$ & $71.33(11)$ & $182.31(988.42)$ & $5.62(6.1)$ & $\begin{array}{l}38.86 \\
(84.34)\end{array}$ \\
\hline Median (IOR) & $10.28(12.25)$ & $25.12(22.65)$ & $59.28(22.36)$ & 71.74 (16.08) & $92.11(36.11)$ & $4(7)$ & $18(53)$ \\
\hline \multicolumn{8}{|l|}{ Total } \\
\hline $\mathrm{N}$ & 10836 & 9876 & 10836 & 10548 & 10548 & 10836 & 10836 \\
\hline Mean (SD) & 13.15 (21.69) & $26.5(27.17)$ & $47.37(30.78)$ & $68.4(14.35)$ & $146.58(752.26)$ & $\begin{array}{l}8.54 \\
(216.56) \\
\end{array}$ & $\begin{array}{l}12.84 \\
(42.47) \\
\end{array}$ \\
\hline Median (IQR) & $8.28(12.8)$ & $21(21.75)$ & 57.5 (55.09) & $69.97(18.26)$ & $91.75(38.3)$ & $4(8)$ & $0(9)$ \\
\hline
\end{tabular}

NICU: Neonatal intensive care unit, PICU: Pediatric intensive care unit, ICU: Intensive care unit, LOS: Length of stay, SD: Standard deviation, IQR: Interquartile range

control committee, designing and implementing the educational programs, paying attention to the basic design of the physical structure of hospital wards, and creating motivational and attitudinal mechanisms in infection control are important factors that can reduce HAls ${ }^{[11]}$.

Device-related infections are a leading cause of HAls, particularly in ICUs. Additionally, catheter-related infections are the most frequent cause of hospital-acquired bacteremia and mechanical complications and are mostly preventable by establishing standard disinfection and sterilization mechanisms and implementing rigorous policies ${ }^{[12,13]}$. Furthermore, mechanical ventilation is a commonly used mode of support in the ICU ${ }^{[11,14]}$. This study revealed that the number of devicerelated infections (catheters and ventilators) was associated with a 10\% increased ICU-Al incidence rate. Moreover, the most common ICU-Als were VAE (38.6\%) and UTI (19.76\%), which are mostly related to the used device. Other studies show that the important infections in the ICU include UTI, pneumonia, and bloodstream infections ${ }^{[7,15,16]}$. Ohannessian et al. ${ }^{[5]}$ revealed that the HAI incidence rate was 14.9 per 1,000 patients-days, and pneumonia and UTI rates were 9.7 and 6.1 per 1,000 patients-days. Furthermore, Choudhuri et al. ${ }^{[17]}$ revealed that pneumonia accounted for more than a third of the observed HAls in the ICUs. The duration of mechanical ventilation, endotracheal intubation, urinary catheterization, and ICU LOS was significantly related to ICU-Als.

Present findings imply that device-related infections are associated with increased complications and costs. Therefore, specific preventive strategies of device-related infections, an established system of reporting and follow-up, and healthcare worker education and training on the use of invasive devices are necessary to reduce ICU-Als. 


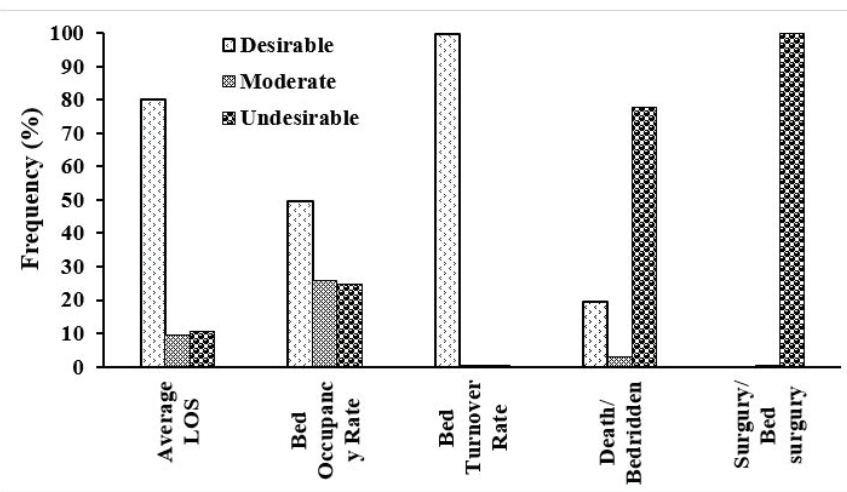

Figure 1. The frequency of hospital indicators in the intensive care unit of Iran hospitals in 2018

LOS: Length of stay

However, our study had some limitations. First, this is a retrospective study, thus some biases are possible. Second, the impact of pathogens, antimicrobial resistance, and other factors on ICU-AI incidence rate was not considered in our study and may limit our interpretation. However, this is a multicenter study and was conducted using registered data, thus it can be claimed that the results are generalizable. Additionally, this study was the first large sample size, comprehensive, and national study that evaluated the associated factors in ICU-AI incidence.

\section{Conclusion}

The results revealed that the internal ICU had the largest increased ICU-AI incidence compared to the NICU and the most common ICU-Als were VAE and UTI. The occurrence of HAls in medical centers is not inevitable and its control is one of the most important health goals of medical centers. Therefore, full hygiene control should be performed by all medical staff to reduce the incidence of ICU-Als. Ventilators and catheters should be used in special circumstances with minimum duration.

\section{Acknowledgments}

This paper was extracted from an epidemiology graduate thesis. We would like to express our thanks to all the staff of the INIS hospital and statistics and information system department of the Ministry of Health of Iran as well as the individuals who help us in completing this research project. The datasets used and/or analyzed during the current study are available from the corresponding author and Ministry of Health and Medical Education on reasonable request.

\section{Ethics}

Ethics Committee Approval: All procedures performed in the study were following the ethical standards of the National Institute for Medical Research Development Research Committee (approval ID=IR.NIMAD.REC.1399.074) and with
Table 2. The frequency of hospital variables in the ICU of Iran hospitals in 2018

\begin{tabular}{|c|c|c|c|}
\hline Variables & & $\mathrm{N}$ & $\%$ \\
\hline \multirow{6}{*}{ Ward type } & $\mathrm{NICU}$ & 2484 & 22.92 \\
\hline & PICU & 624 & 5.76 \\
\hline & Internal ICU & 1476 & 13.62 \\
\hline & General ICU & 4704 & 43.41 \\
\hline & Surgical ICU & 1548 & 14.29 \\
\hline & Total & 10836 & 100 \\
\hline \multirow{4}{*}{ Hospital type } & Educational-therapy & 3168 & 31.92 \\
\hline & Therapy & 6132 & 61.79 \\
\hline & Educational-therapy-research & 624 & 6.29 \\
\hline & Total & 9924 & 100 \\
\hline \multirow{10}{*}{$\begin{array}{l}\text { Hospital } \\
\text { expertise }\end{array}$} & General & 8952 & 90.53 \\
\hline & Pediatry & 300 & 3.03 \\
\hline & Gynecology & 276 & 2.79 \\
\hline & Psychiatry & 36 & 0.36 \\
\hline & Trauma & 48 & 0.49 \\
\hline & Cardiovascular & 156 & 1.58 \\
\hline & Orthopedy & 24 & 0.24 \\
\hline & Oncology & 84 & 0.85 \\
\hline & Surgery & 12 & 0.12 \\
\hline & Total & 9888 & 100 \\
\hline \multirow{4}{*}{ Accreditation } & Excellent & 456 & 4.61 \\
\hline & 1 & 8628 & 87.26 \\
\hline & 2 & 804 & 8.13 \\
\hline & Total & 9888 & 100 \\
\hline \multirow{5}{*}{ Affiliation } & Government & 7572 & 71.46 \\
\hline & Semi-government & 528 & 4.98 \\
\hline & Profit & 1992 & 18.8 \\
\hline & Non-Profit/other & 504 & 4.76 \\
\hline & Total & 10596 & 100 \\
\hline \multirow{6}{*}{$\begin{array}{l}\text { Hospital- } \\
\text { based on bed } \\
\text { size }\end{array}$} & Small (<100 bed) & 1860 & 17.55 \\
\hline & Medium (100-320) & 6768 & 63.87 \\
\hline & Large (320-600) & 1464 & 13.82 \\
\hline & X-Large (600-1000) & 456 & 4.3 \\
\hline & Hospital complex (>1000) & 48 & 0.45 \\
\hline & Total & 10596 & 100 \\
\hline \multirow{5}{*}{ Pabon Lasso } & Zone I (not efficient) & 2964 & 27.35 \\
\hline & Zone II & 276 & 2.55 \\
\hline & Zone III (efficient) & 1788 & 13.73 \\
\hline & Zone IV & 6108 & 56.37 \\
\hline & Total & 10836 & 100 \\
\hline
\end{tabular}

NICU: Neonatal intensive care unit, PICU: Pediatric intensive care unit, ICU: Intensive care unit

the 1964 Helsinki Declaration and its later amendments or comparable ethical standards.

Informed Consent: Retrospective study.

Peer-review: Externally and internally peer-reviewed. 
Table 3. The univariable and multivariable generalized negative binomial regression between ICU-Als incidence and hospital variables and indicators in Iran hospitals

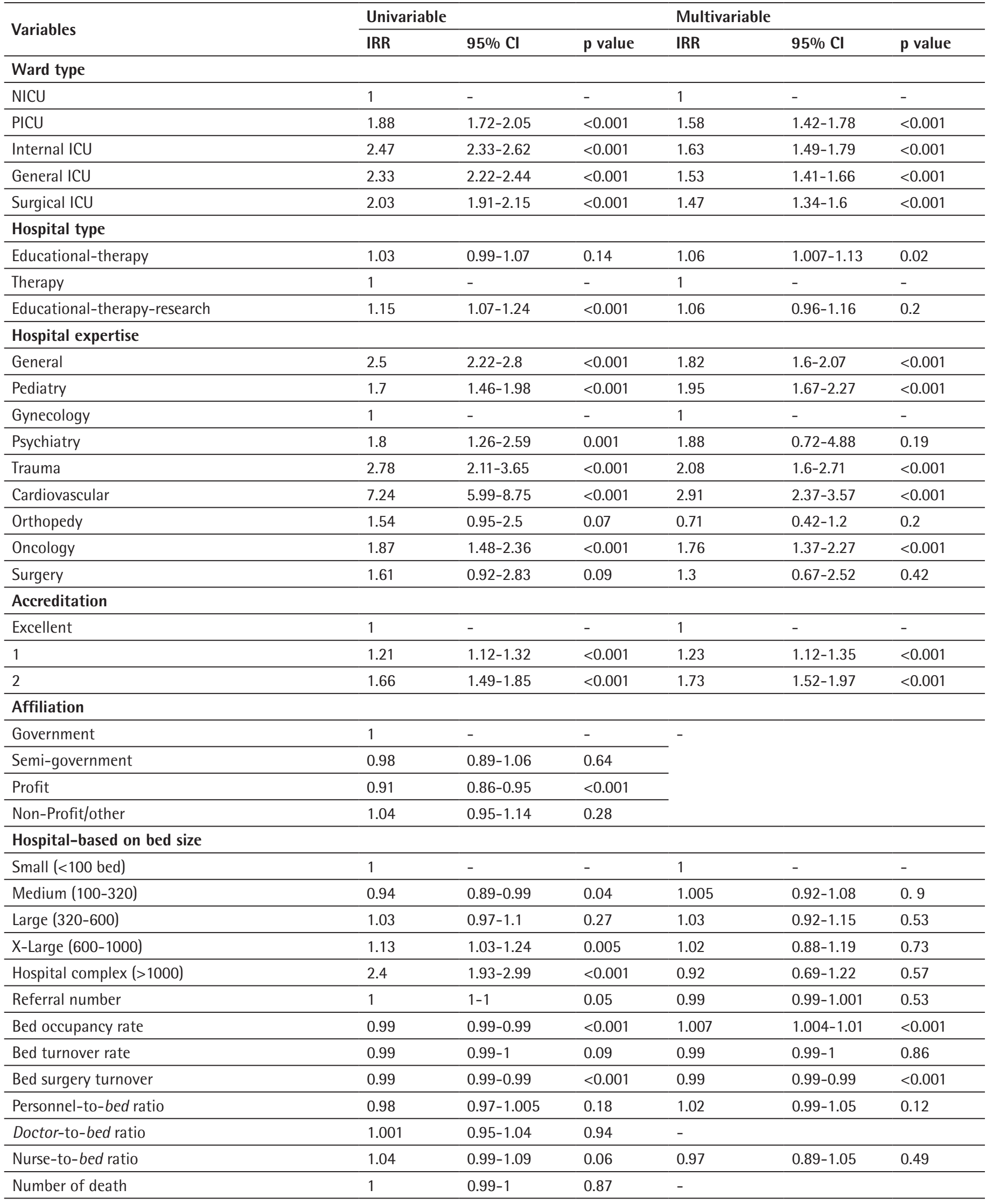




\begin{tabular}{|c|c|c|c|c|c|c|}
\hline Number of surgery & 1.0005 & $1.00007-1.001$ & 0.02 & 0.99 & $0.99-1.0001$ & 0.33 \\
\hline Device-day & 1.00006 & $\begin{array}{l}1.00003- \\
1.00009\end{array}$ & $<0.001$ & 0.99 & $0.99-1.0001$ & 0.39 \\
\hline Catheter-day & 1.00004 & $\begin{array}{l}1.00001- \\
1.00008\end{array}$ & 0.006 & 0.99 & $0.99-1.0001$ & 0.31 \\
\hline Ventilator-day & 1.0007 & $1.0005-1.0008$ & $<0.001$ & - & & \\
\hline Mean age & 1.007 & $1.006-1.008$ & $<0.001$ & 1.0007 & $0.99-1.001$ & 0.16 \\
\hline hospitalization length until infection & 1.0008 & $0.99-1.001$ & 0.86 & - & & \\
\hline Hospital LOS & 1.0001 & $0.99-1$ & 0.69 & - & & \\
\hline Male-to-patients ratio & 0.99 & $0.99-0.99$ & 0.04 & 0.99 & $0.99-1.0006$ & 0.86 \\
\hline Number of death (in HAls patients) & 1.09 & $1.08-1.09$ & $<0.001$ & 1.02 & $1.01-1.02$ & $<0.001$ \\
\hline Ventilator-related infections & 1.09 & $1.09-1.1$ & $<0.001$ & 0.99 & $0.99-1.001$ & 0.37 \\
\hline Catheter-related infections & 1.09 & $1.08-1.1$ & $<0.001$ & 0.99 & $0.99-1.0001$ & 0.24 \\
\hline Device-related infections & 1.05 & $1.05-1.06$ & $<0.001$ & 1.1 & $1.08-1.13$ & $<0.001$ \\
\hline \multicolumn{7}{|l|}{ Pabon Lasso } \\
\hline Zone I (not efficient) & 1.03 & $0.97-1.1$ & 0.25 & \multirow[t]{4}{*}{-} & & \\
\hline Zone II & 0.96 & $0.84-1.1$ & 0.61 & & & \\
\hline Zone III (efficient) & 1 & - & - & & & \\
\hline Zone IV & 1.03 & $0.97-1.09$ & 0.21 & & & \\
\hline \multicolumn{7}{|l|}{ Average LOS indicator } \\
\hline Desirable & 1 & - & - & 1 & - & - \\
\hline Moderate & 1.09 & $1.03-1.16$ & 0.002 & 0.85 & $0.79-0.91$ & $<0.001$ \\
\hline Undesirable & 1.02 & $0.97-1.08$ & 0.31 & 0.79 & $0.57-1.005$ & 0.052 \\
\hline \multicolumn{7}{|l|}{ Bed occupancy rate indicator } \\
\hline Desirable & 1 & - & - & 1 & - & - \\
\hline Moderate & 1.03 & $0.98-1.07$ & 0.17 & 1.17 & $1.09-1.25$ & $<0.001$ \\
\hline Undesirable & 1.03 & $0.98-1.08$ & 0.14 & 1.07 & $0.96-1.19$ & 0.16 \\
\hline \multicolumn{7}{|l|}{ Bed turnover rate indicator } \\
\hline Desirable & 1 & - & - & \multirow[t]{4}{*}{-} & & \\
\hline Moderate & 1.005 & $0.62-1.62$ & 0.98 & & & \\
\hline Undesirable & 0.9 & $0.53-1.54$ & 0.72 & & & \\
\hline \multicolumn{6}{|l|}{ Death-to-bedridden ratio } & \\
\hline Desirable & 1 & - & - & \multirow[t]{3}{*}{-} & & \\
\hline Moderate & 0.95 & $0.85-1.07$ & 0.48 & & & \\
\hline Undesirable & 1.48 & $1.4-1.56$ & $<0.001$ & & & \\
\hline
\end{tabular}

NICU: Neonatal intensive care unit, PICU: Pediatric intensive care unit, ICU: Intensive care unit, LOS: Length of stay, HAls: Hospital-acquired infections; IRR: Incidence rate ratio, CI: Confidence interval

\section{Authorship Contributions}

Concept and Design: N.I., Y.M., K.E., B.E., S-S.H-N., Data Collection or Processing: B.E., S-S.H-N., Analysis or Interpretation: N.I., Y.M., B.E., S-S.H-N., Writing: N.I., K.E., S-S.H-N.

Conflict of Interest: No conflict of interest was declared by the authors.

Financial Disclosure: This study was supported by National Institute for Medical Research Development Grant No: 988979.

\section{References}

1. World Health Organization. Report on the burden of endemic health careassociated infection worldwide, 2011.

2. Chastre J, Luyt CE, Wolff M. Serious Infections in the ICU: Evolving Concepts in Management and Prevention. Semin Respir Crit Care Med. 2019;40:4178.

3. Magill SS, Edwards JR, Bamberg W, Beldavs ZG, Dumyati G, Kainer MA Lynfield R, Maloney M, McAllister-Hollod L, Nadle J, Ray SM, Thompson DL, Wilson LE, Fridkin SK; Emerging Infections Program Healthcare-Associated Infections and Antimicrobial Use Prevalence Survey Team. Multistate point-prevalence survey of health care-associated infections. N Engl J Med. 2014;370:1198-208. 
4. De Angelis G, Murthy A, Beyersmann J, Harbarth S. Estimating the impact of healthcare-associated infections on length of stay and costs. Clin Microbiold Infect. 2010;16:1729-35.

5. Ohannessian R, Gustin MP, Bénet T, Gerbier-Colomban S, Girard R, Argaud L, Rimmelé T, Guerin C, Bohé J, Piriou V, Vanhems P. Estimation of extra length of stay attributable to hospital-acquired infections in adult ICUs using a time-dependent multistate model. Crit Care Med. 2018;46:1093-8.

6. Edwardson S, Cairns C. Nosocomial infections in the ICU. Anaesthesia \& Intensive Care Medicine. 2019;20:14-8.

7. Inan D, Saba R, Yalcin AN, Yilmaz M, Ongut G, Ramazanoglu A, Mamikoglu L. Device-associated nosocomial infection rates in Turkish medical-surgical intensive care units. Infect Control Hosp Epidemiol. 2006;27:343-8.

8. Ling ML, Apisarnthanarak A, Madriaga G. The Burden of HealthcareAssociated Infections in Southeast Asia: A Systematic Literature Review and Meta-analysis. Clin Infect Dis. 2015;60:1690-9.

9. Despotovic A, Milosevic B, Milosevic I, Mitrovic N, Cirkovic A, Jovanovic $\mathrm{S}$, Stevanovic G. Hospital-acquired infections in the adult intensive care unit-Epidemiology, antimicrobial resistance patterns, and risk factors for acquisition and mortality. Am J Control. 2020;48:1211-5.

10. Timsit JF, Rupp $M$, Bouza $E$, Chopra $V$, Kärpänen $T$, Laupland $K$, Lisboa $T$, Mermel L, Mimoz O, Parienti JJ, Poulakou G, Souweine B, Zingg W. A state of the art review on optimal practices to prevent, recognize, and manage complications associated with intravascular devices in the critically ill. Intensive Care Med. 2018;44:742-59.

11. Liang J, Li Z, Dong $H, X u C$. Prognostic factors associated with mortality in mechanically ventilated patients in the intensive care unit: a single- center, retrospective cohort study of 905 patients. Medicine (Baltimore). 2019;98:e17592.

12. Buetti N, Timsit JF. Management and prevention of central venous catheterrelated infections in the ICU. Semin Respir Crit Care Med. 2019;40:508-23.

13. van der Kooi $T$, Sax $H$, Pittet $D$, van Dissel J, van Benthem B, Walder $B$, Cartier V, Clack L, de Greeff $S$, Wolkewitz M, Hieke $S$, Boshuizen $H$, van de Kassteele J, Van den Abeele A, Boo TW, Diab-Elschahawi M, Dumpis U, Ghita C, FitzGerald S, Lejko T, Leleu K, Martinez MP, Paniara O, Patyi M, Schab P, Raglio A, Szilágyi E, Ziętkiewicz M, Wu AW, Grundmann H, Zingg W; PROHIBIT consortium. Prevention of hospital infections by intervention and training (PROHIBIT): results of a pan-European cluster-randomized multicentre study to reduce central venous catheter-related bloodstream infections. Intensive Care Med. 2018;44:48-60.

14. Fialkow L, Farenzena M, Wawrzeniak IC, Brauner JS, Vieira SR, Vigo A, Bozzetti MC. Mechanical ventilation in patients in the intensive care unit of a general university hospital in southern Brazil: an epidemiological study. Clinics (Sao Paulo). 2016;71:144-51.

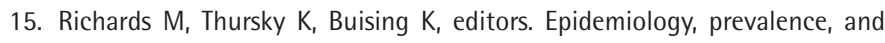
sites of infections in intensive care units. Semin Respir Crit Care Med. 2003;24:3-22.

16. Ramritu $P$, Halton K, Cook D, Whitby $M$, Graves N. Catheter-related bloodstream infections in intensive care units: a systematic review with meta-analysis. J Adv Nurs. 2008;62:3-21.

17. Choudhuri AH, Chakravarty M, Uppal R. Epidemiology and characteristics of nosocomial infections in critically ill patients in a tertiary care intensive care unit of Northern India. Saudi J Anaesth. 2017;11:402-7. 